\title{
BIO-GAS AND THE GAS GENERATION OF ORGANIC BIOMASS
}

\section{Medvediev M. H.}

\section{The history of bio-gas technology development}

The first scientific substantiation of marsh gas combustion, the determination of the presence of methane in marsh gas and methane fermentation were discovered and investigated in 1776 by Volt. After discovering the chemical formula of methane by Dalton in 1804, European scientists took the first steps in the study of the practical application of biogas.

Biogas is formed as a result of anaerobic fermentation of organic materials. Being a product of metabolism and present in organic waste of methane bacteria which produces biogas. A prerequisite for biogas production is the productive activity of methane-forming bacteria.

Today it is known that this is a lack of oxygen, $\mathrm{pH}-$ from 6.5 to 7.5 and constant temperature from 15 to $55^{\circ} \mathrm{C}$. The fermentation period is from 10 to 120 days, depending on the conditions regulated by the above parameters, namely the $\mathrm{pH}$ factor and the temperature of the environment.

\subsection{The main stages of methane fermentation}

Methane fermantation is the process of decomposing organic matter to end products, mainly methane and carbon dioxide, due to the vital activity of a complex of microorganisms under anaerobic conditions. Under optimal conditions, these gases are formed in the amount of $90 . .95 \%$ of decomposed organic matter. The remaining $5 \ldots 10 \%$ are spent on bacterial cell renewal.

According to McCarthy's theory, the complete destruction of organic matter is as follows:

$$
\mathrm{C}_{10} \mathrm{H}_{19} \mathrm{O}_{3} \mathrm{~N}+4,5 \mathrm{H}_{2} \mathrm{O} \rightarrow 6,25 \mathrm{CH}_{4}+3,75 \mathrm{CO}_{2}+\mathrm{NH}_{3}+\mathrm{HCO}_{3}
$$

According to modern concepts, anaerobic methane fermentation has four related stages: 
1. Stage of enzymatic hydrolysis of insoluble complex organic substances with the formation of simple soluble substances;

2. Stage of acid-forming process with the release of volatile fatty acids (VFA), amino acids, alcohols, hydrogen and carbon dioxide (acidogenic stage);

3. Acetogenic stage of conversion of VFA, amino acids and alcohols to acetic acid;

4. The methanogenic stage is the formation of methane from acetic acid and the recovery of carbon dioxide by hydrogen.

Enzymatic hydrolysis takes place with the help of the enzymatic bacteria Bacillus, Micrococcus, Pseudomonas, Clostridium, etc., which convert organic complex compounds into simple ones by enzymatic hydrolysis and acid formation. These bacteria at $\mathrm{pN}=6,5 \ldots 7,6$ quickly grow and release into the environment biological catalysts - exoenzymes, with the participation of which the hydrolysis and transition of soluble insoluble compounds into soluble state proceeds. The rate of hydrolysis depends on the nature of the organic matter and the conditions of its conduct: it is necessary to provide a sufficient number of enzymes, to create conditions for their contact with the organic substrate, to maintain optimal temperatures and $\mathrm{pH}$ values.

The acidogenic stage occurs with the help of heterogeneous microorganisms, for which carbon, which is converted into a solution of simple organic compounds, is a source of nutrition. Stages of acid formation occur quickly, because the acid-forming bacteria are unpretentious and multiply at high speed. The intense course of hydrolysis and acid formation (total duration of about 7 hours) leads to the accumulation of volatile acids and $\mathrm{pH}$ decrease, which suppresses the bacterial growth and stimulates methanogenesis.

In the third acetogenic stage, the first group of bacteria, for example from propionic and butyric acids, acetic acid and hydrogen are formed.

$\mathrm{CH}_{3} \mathrm{CH}_{2} \mathrm{COOH}+2 \mathrm{H}_{2} \mathrm{O} \rightarrow \mathrm{CH}_{3} \mathrm{COOH}+\mathrm{CO}_{2}+3 \mathrm{H}_{2}$

$\mathrm{CH}_{3} \mathrm{CH}_{2} \mathrm{CH}_{2} \mathrm{COOH}+2 \mathrm{H}_{2} \mathrm{O} \rightarrow 2 \mathrm{CH}_{3} \mathrm{COOH}+2 \mathrm{H}_{2}$

The second group of acetogenic bacteria forms acetic acid by recovery of carbon dioxide with hydrogen.

$$
4 \mathrm{H}_{2}+2 \mathrm{CO}_{2} \rightarrow \mathrm{CH}_{3} \mathrm{COOH}+2 \mathrm{H}_{2} \mathrm{O}
$$


In the fourth methanogenic stage, methane bacteria form methane in two ways - the splitting of acetate (acetic acid) and the recovery of carbonic acid by hydrogen.

$$
\begin{gathered}
\mathrm{CH}_{3} \mathrm{COOH} \rightarrow \mathrm{CH}_{4}+\mathrm{CO}_{2} \\
\mathrm{CO}_{2}+\mathrm{H}_{2} \rightarrow \mathrm{CH}_{4}+\mathrm{H}_{2} \mathrm{O} \\
\mathrm{CO}_{2}+\mathrm{H}_{2} \rightarrow \mathrm{CH}_{4}+\mathrm{H}_{2} \mathrm{O}
\end{gathered}
$$

The simplest process of methane fermentation takes place in watertight tanks (digesters) with a side opening through which the enzymatic raw material is introduced. A gas container (metal or plastic) is installed above the digester to collect gas. Mounted over the fermenting biomass, dome container prevents air from entering the dome and provides anaerobic process conditions.

Lime is used as a stabilizer against acidification. Optimal "breathing" in the methane tank occurs under conditions close to neutral $(\mathrm{pH}=6.0 \ldots 8.0)$. The maximum temperature of the process depends on the mesophilicity or thermophilicity of the microorganisms $\left(30 \ldots 40^{\circ} \mathrm{C}\right.$ or $50 \ldots 60^{\circ} \mathrm{C}$ ) sudden changes in temperature are undesirable.

In terms of the nutritional requirements of the bacteria, excess nitrogen (eg in the case of liquid manure) contributes to the accumulation of ammonia, which suppresses the bacterial growth. For optimal processing, the $\mathrm{C} / \mathrm{N}$ ratio should be 30 : 1 (by weight). This ratio can be varied by mixing nitrogen-enriched components with carbon-enriched components. So, the ratio of manure can be varied by the addition of straw or sugar beet pulp. Food and agricultural wastes have a significant amount of carbon, so they are best suited for methane fermentation, especially since some of them (pulp) are produced at the temperature most optimal for the process.

Biogas production through methane "fermentation" of waste is one of the ways to solve energy, economic, environmental, agrochemical problems in most countries of the world.

Biogas is a mixture of methane $(60 \ldots 85 \%)$ and carbon dioxide $(15 \ldots 40 \%)$. It is obtained in special installations of various constructive designs, depending on local conditions.

The heat of solid fuel combustion, such as coal, is $6 \ldots 32 \mathrm{MJ} / \mathrm{kg}$. Biogas has a combustion heat of $21 \ldots 36 \mathrm{MJ} / \mathrm{kg}$ under normal conditions. From a ton of organic matter from 250 to $600 \mathrm{~m}^{3}$ of biogas are released . After the methane process, compost residue. Different substances produce 
not the same amount of biogas. It should be noted that by adding up to $30 \%$ of cellulose to biomass, the biogas output increases by $2 \ldots 3$ times.

A kilo of manure gives: $0.18 \mathrm{~kg}$ of methane, $0.32 \mathrm{~kg}$ of carbon dioxide, $0.2 \mathrm{~kg}$ of water and $0.3 \mathrm{~kg}$ of humus. One kilogram of biogas gives heat that emits $0.6 \mathrm{~kg}$ of kerosene, $1.5 \mathrm{~kg}$ of coal, $2 \ldots 3 \mathrm{~kg}$ of firewood. Today more than 70 types of biogas technologies have been developed.

\subsection{The hardware realization of bio-gas production}

The biogas plant produces biogas and biofertilizers from the biowaste of the agro-industrial complex of the food and processing industry through methane treatment.

According to temperature regimes, biogas production is divided into psychrophilic $\left(15 \ldots 20^{\circ} \mathrm{C}\right)$, mesophilic $\left(30 \ldots 40^{\circ} \mathrm{C}\right)$ and thermophilic $\left(52 \ldots 56{ }^{\circ} \mathrm{C}\right)$. The average time of origin in mesophilic mode is $15 \ldots 30$ days, in thermophilic $-5 \ldots 10$ days.

Fig. 1 presents a schematic diagram of continuous anaerobic processing of organic waste.

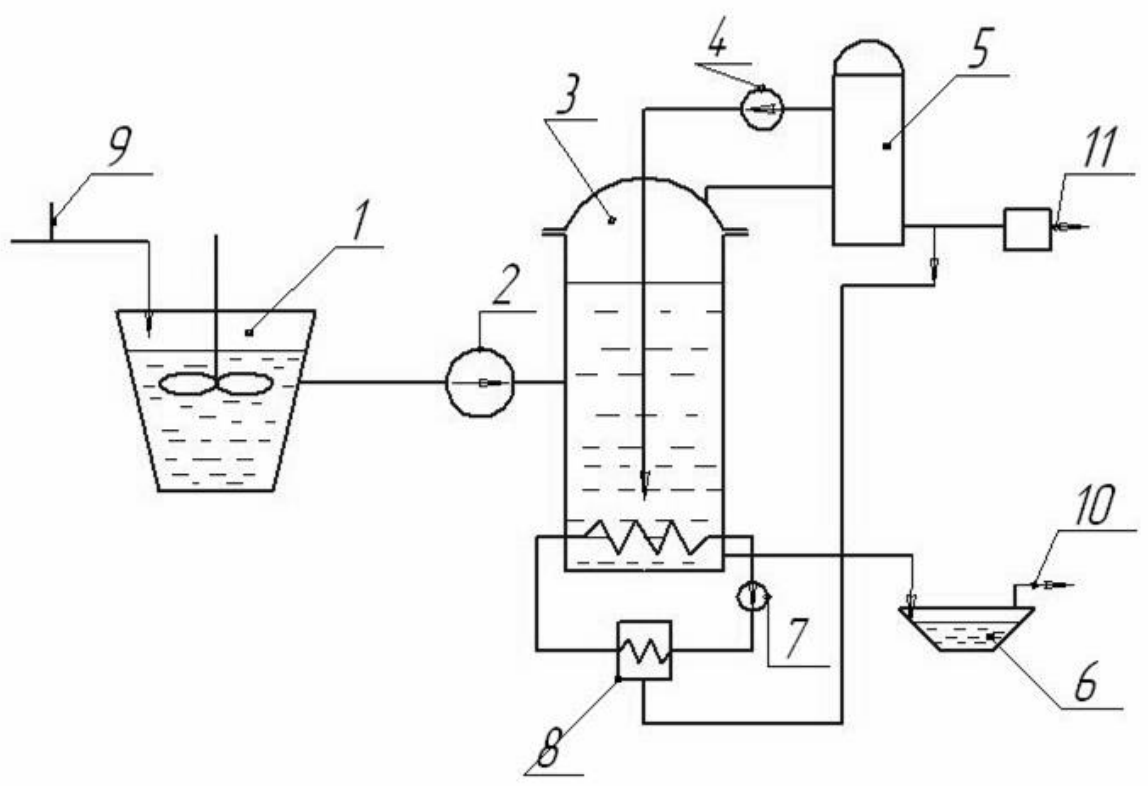

Fig. 1. Scheme of continuous anaerobic processing of organic waste:

1 - tank for the preparation of raw materials; 2 - metering pump; 3 - methane tank; 4 - compressor; 5 - gas holder; 6 - compost collector; 7 - circulation pump; 8 - a boiler for maintaining the temperature of methane tank; 9 - supply of raw materials; 10 - fertilizers for use; 11 - gas filter; 12 - biogas for use. 
Organic waste is supplied into the raw material preparation tanks (1), in which grinding, mixing, removal of solids, mass moisture up to $88 \ldots 90 \%$ and other operations take place. The prepared raw material is supplied by metering pumps (2) to the methane tank (3), where the process of fermentation occurs under the action of methane-forming bacteria. The generated biogas is discharged from the upper part of the methane tank into the gas holder (5), from where it comes to the consumers. The residues of the fermented raw materials (decontaminated fertilizers) from the lower part are supplied into the waste collector (6) from which they are taken to the field.

In order to maintain the set temperature in the methane tanks, hot water heated in the boilers (8) is pumped through the coil pipes. Such heating consumes $20 \ldots 30 \%$ of the produced biogas. Depending on the time of fermentation of raw materials, the required volume of methane tanks and the amount of raw material supplied for dispensing by the pumps are determined.

To accelerate the fermentation process, part of the biogas is supplied back from the gas holder by compressor (4) to the methane tank.

The installation consists of two reactors, a heater, a fecal and screw pumps, a gas holder, a compressor, a boiler.

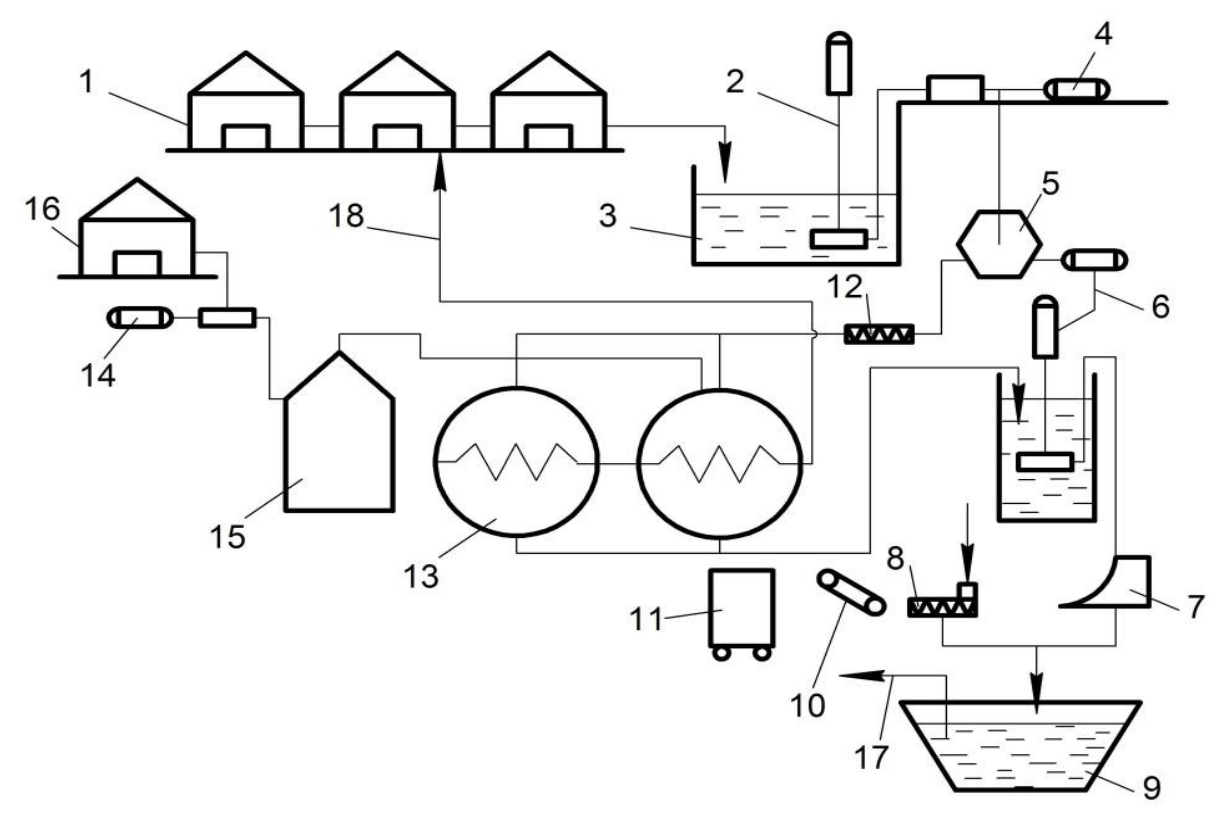

Fig. 2. Technological flowchart of biogas plant:

1 - farm; 2 - pump for liquid pulp; 3 - collector; 4 - granulator; 5 - heater-holder; 6 - pumps for liquid manure; 7 - arc sieves; 8 - press filter; 9 - manure storage; 10 - conveyor; 11 - tractor trailer; 12 - screw pump; 13 - methane tank reactor; 14 - compressor; 15 - gas holder; 16 - boiler; 17 - fertilizers for use. 
The waste from the farm flows into the collector (3). Various organic wastes can be added to the collector. The mixture from the collector (3) is pumped into the granulator (4) and then into the heater-holder (5).

The heater-holder (5) is a $25 \mathrm{~m}^{3}$ tank with a heat exchanger where the manure is heated to the required temperature. From the heater-holder (5), the mixture is pumped with a screw pump - dispenser (12) to the reactor (13), where biogas is released, which is pumped by the compressor for cleaning into the gas holder (15). The gas is then fed to the gas boiler (16) for use by a compressor (14) through a water valve and a non-return valve. Inloads can be regulated automatically.

In various designs of biogas plants, the process mixture is divided into solid and liquid parts. The thick mass is passed through a press filter for dewatering up to $75 \%$, and water is used as a technical water for industrial purposes.

\subsection{The formulas for the calculation of the parameters of biogas plant}

Most biogas plants are based on the the streaming principle of action, that is, they have input raw materials that immediately displace waste. Fresh manure is supplied continuously ( $2 \ldots 10$ times a day), and biogas and sludge removal are done as needed.

The biogas plant consists of the following elements: receiving tanks, a fermentation chamber (methane tank, reactor), a heating device (heat exchanger), a device for mixing the substrate, a gas holder and a gas water heater.

Raw material from the loading bunker enters the methank, where it is fermented, resulting in biogas coming through the water gate into the gas holder. Part of the biogas is sent to the boiler to maintain the required temperature in the methane tank. The biomass is mixed by an electric motor stirrer. Used methane tank raw material is supplied into biofertilizer storage.

Calculations of structural and technological parameters.

The daily supply of biomass $m_{б м}$ is determined by the formula:

$$
m_{\sigma м}=\sum N_{m j} m_{n m j}, \kappa 2 / \text { добy, }
$$

where $N_{m}$ - number of animals of the j-th species, heads; $m_{n m j}$ - daily output of excrement from the $\mathrm{j}$-th animal, $\mathrm{kg} / \mathrm{h}$. 
The proportion of dry matter in biomass $m_{C P}$ :

$$
m_{C P}=m_{б м} \cdot\left(1-\frac{\varphi_{\sigma м}}{100}\right)
$$

where $\varphi_{{ }_{\sigma}}$ - biomass moisture, $\%$.

Let us determine the proportion of dry organic matter $\mathrm{m}_{\mathrm{COP}}$ by the formula:

$$
m_{C O P}=m_{C P} \cdot \rho_{C O P},
$$

where $\rho_{C O P}$ is the proportion of organic matter in the dry matter, $\%$.

Let us determine the volume of methane tank $\mathrm{V}_{\mathrm{MT}}$ by the formula

$$
V_{\text {мm }}=\frac{(0,7 \ldots 0,9) m_{\sigma \mu} t_{\sigma}}{\rho_{\sigma м}},
$$

where $t_{\sigma}-$ duration of fermentation, days; $\rho_{\sigma m}-$ density of the fermented biomass, $\mathrm{kg} / \mathrm{m}^{3}$.

Biogas output $V_{\text {nов }}, \mathrm{m}^{3}$, with complete decomposition of dry organic matter (DOM):

$$
V_{\text {пов }}=m_{C O P} \cdot n_{e \kappa},
$$

where $n_{e \kappa}$ - biogas output from $1 \mathrm{~kg}$ of DOM.

let us determine the amount of biogas obtained $V_{\sigma}, \mathrm{m}^{3}$, with the selected duration of methane fermentation:

$$
V_{\sigma}=V_{\text {пов }} \frac{n_{t}}{100},
$$

where $n_{t}$ is the fraction of biogas output at the given fermentation time.

Monthly volume of biogas produced:

$$
V_{\sigma 2}^{\mu}=30 \cdot V_{\sigma}, M^{3} .
$$

Annual volume of biogas produced

$$
V_{\sigma 2}^{p}=365 \cdot V_{\sigma}, M^{3} \text {. }
$$

Calculation of the dimensions of the methane tank

As a rule, the methane tanks have a cylindrical shape, the ratio of height to its inner diameter is assumed to be $\mathrm{h} / \mathrm{d}=0.9 \ldots 1.3$. We accept $\mathrm{h} / \mathrm{d}=1$. 


$$
\begin{gathered}
V_{M m}=\frac{\pi d_{b}^{2}}{4} \cdot h=\frac{\pi d_{b}^{2}}{4} \cdot d_{B}, \\
d_{B}=\sqrt[3]{\frac{4 V_{M m}}{\pi}}, \mathcal{M} .
\end{gathered}
$$

Determination of the average monthly amount of biogas.

The amount of heat $Q_{n i d}$, is required to heat the loading mass to the temperature of the fertilization process:

$$
Q_{\text {niठ }}=m_{б м} \cdot c_{б м} \cdot\left(t_{n p}-t_{\text {зав }}\right) \cdot 10^{-3} \text { мДжс, }
$$

where $c_{\sigma м}$ - average biomass heat capacity, $c_{\sigma м}=4.18 \mathrm{~kJ} /\left(\mathrm{kg} \cdot{ }^{\circ} \mathrm{C}\right)$; $t_{n p}-$ fermentation process temperature, ${ }^{\circ} \mathrm{C} ; t_{3 a в}-$ loading biomass temperature ${ }^{\circ} \mathrm{C}$. We assume equal to the average monthly environment temperature, if less than $5^{\circ} \mathrm{C}$, then $5^{\circ} \mathrm{C}$ is accepted.

The monthly average amount of heat is determined by the expression:

$$
Q_{n i \partial}^{M}=Q_{n i \partial} \cdot t_{\partial о \sigma}^{M},
$$

where $t_{\text {доб }}{ }^{\mathrm{M}}-$ the number of days in a month, $\mathrm{t}_{\text {доб }}{ }^{\mathrm{M}}$ we accept equal to 30 days.

The amount of heat $Q_{\text {smp }}$, that is lost in the process of heat transfer through the wall of the methane tank to the environment:

$$
Q_{\text {вmp }}=k \cdot f \cdot\left(t_{n p}-t_{c p}\right) B m,
$$

where $\mathrm{k}$ - the heat transfer coefficient, $\mathrm{W} /\left(\mathrm{m}^{2} \cdot{ }^{\circ} \mathrm{C}\right) ; \mathrm{f}-$ the surface square of the methank, $\mathrm{m}^{2} ; \mathrm{t}_{\mathrm{cp}}$ - average monthly air temperature, ${ }^{\circ} \mathrm{C}$.

The heat release coefficient is determined by the formula:

$$
k=\frac{1}{\frac{1}{\alpha_{1}}+\sum_{i=1}^{n} \frac{\delta_{i}}{\lambda_{i}}+\frac{1}{\alpha_{2}}} B m /\left(M^{2} \cdot C\right),
$$

where $1 / \alpha_{1}$ - resistance of heat perception, $1 / \alpha_{1}=0,05\left(\mathrm{~m}^{2} \cdot{ }^{\circ} \mathrm{C}\right) / \mathrm{W}$; $1 / \alpha_{2}$ - heat transfer resistance, $1 / \alpha_{2}=0.05\left(\mathrm{~m}^{2} \cdot{ }^{\circ} \mathrm{C}\right) / \mathrm{W} ; \delta$ and - the thickness of the $i$-th layer of the fence element, $m ; \lambda_{i}-$ coefficient of thermal conductivity of the $\mathrm{i}$-th layer of the fence element, $\mathrm{m} \cdot{ }^{\circ} \mathrm{C} / \mathrm{W}$. 
The surface area of the methane tank will be determined from the expression:

$$
F=S_{\sigma i \varphi}+2 \cdot S_{o c h}, M^{2},
$$

where $S_{\text {бiч }}$ is the area of the lateral surface of the methank, $\mathrm{m}^{2}$;

$\mathrm{S}_{\text {осн }}-$ metanthanese base area, $\mathrm{m}^{2}$.

$$
\begin{gathered}
S_{O C H}=\frac{\pi d_{B}^{2}}{4}, M^{2} . \\
S_{\text {бiч }}=\pi \cdot d_{B} \cdot h=\pi \cdot d_{B}^{2}, M^{2} .
\end{gathered}
$$

Transfer of the amount of heat, lost to the environment, into $\mathrm{MJ} / \mathrm{mo}$ :

$$
Q_{\text {вmp }}^{\mu}=3,6 \cdot 10^{-3} \cdot Q_{6 m p} \cdot t_{2 M} \text {. }
$$

where $t_{\text {гм }}$ is the number of hours in a month.

The total energy consumption for mechanical stirring of the substrate in the methane tank $\mathrm{Q}_{\text {мех }}$ is determined by the formula

$$
Q_{\text {мех }}=q_{\text {норм }} \cdot V_{\text {мm }} \cdot z, \kappa B m \cdot \text { год, }
$$

where $q_{\text {норм }}-$ specific load on the stirrer, $q_{\text {норм }}=50 \frac{\mathrm{Bm} \cdot \text { год }}{\mathrm{M}^{3}}$; $V_{\text {um }}$ - methane tank volume, $\mathrm{m}^{3} ; z$ - stirrer life, $z=8$ hours a day.

We transfer the obtained values in $\mathrm{MJ} / \mathrm{month}$ :

$$
Q_{\text {мex }}^{M}=3,6 \cdot Q_{\text {мех }} \cdot t_{\text {доб }}^{M} .
$$

Total energy flow rates for support of the process per month:

$$
Q_{\text {заг }}=Q_{\text {nid }}^{M}+Q_{\text {вmp }}^{m}+Q_{\text {меx }}^{M}, \text { МДж / мiс. }
$$

The amount of biogas required to support the process:

$$
V_{\text {без }}^{\mu}=Q_{3 a 2} / q_{62}, M^{3} / \text { мic. }
$$

The product quantity of biogas $\mathrm{V}_{\text {бг тов }}{ }^{\mathrm{M}}, \mathrm{m}^{3} /$ month, will be equal to:

$$
V_{\text {бгтов }}^{\stackrel{\mu}{M}}=V_{\text {бг }}^{M}-V_{\text {бгз }}^{M} \text {. }
$$


Calculations of energy efficiency indicators of biogas plant.

The potential energy of biogas $Q_{\text {отp }}$ produced in a year is determined by the formula:

$$
Q_{\text {omp }}=V_{\sigma 2}^{p i \kappa} \cdot q_{б \varepsilon}, \text { МДж. }
$$

Energy effect of biogas plant $Э_{\bar{\sigma}}$ per year:

$$
Э_{\bar{\sigma}}=V_{\text {бгтов }}^{\text {рiк }} \cdot q_{б \varepsilon}, \text { мДж. }
$$

Venality ratio of biogas plant

$$
K_{\text {mos }}=\frac{\ni_{\sigma}}{Q_{\text {omp }}} \cdot 100 \% .
$$

Annual savings of conventional fuel will be:

$$
B_{y n}=\frac{Э_{\sigma}}{29300} .
$$

\section{The theoretical basis of the process of gasification of plant biomass}

Gasification is a process of intense exothermic oxidation, in which the reaction of carbon with carbon dioxide and water vapor with the formation of combustible gases $\left(\mathrm{CO}, \mathrm{H}_{2}, \mathrm{CH}_{4}\right.$, etc.) takes place. With excess oxygen, the gasification process goes into the combustion process, characterized by maximum heat release (endothermic reaction).

It is established that the whole process of gasification can be divided into three stages:

1 - heating and drying of plant biomass;

2 - thermal decomposition of raw materials into gaseous products and solid residue;

3 - gasification of the carbon residue.

In the first stage, the plant biomass is heated to a temperature of about $250{ }^{\circ} \mathrm{C}$. At this temperature, at high heating rates, due to the increase in pressure, the walls of plant biomass cells break with the release of bound moisture from organic raw materials in the form of steam.

It is established that at $2003 \mathrm{a} 300{ }^{\circ} \mathrm{C}$ the biomass begins to react and at $400{ }^{\circ} \mathrm{C}$ the thermal decomposition ends. It should be noted that the main components because of thermal decomposition, of wood for example, are cellulose, lignin and hemicellulose. 
It is noted that at high temperatures and small particle size of the raw material the process of gasification takes place, and at low temperatures and large particle size, and in the presence of moisture in the raw materials - the formation of carbonaceous matter, water and $\mathrm{CO}_{2}$.

If the process of gasification is only due to the oxygen of the air, then the so-called air gas is formed, which mainly consists of carbon monoxide and nitrogen passing from the air, as well as a small amount of carbon dioxide. When used as a blast of water vapor these are formed: hydrogen, carbon monoxide and carbon dioxide, which are mixed with water vapor. This mixture is called - water gas. When simultaneously used as a blast of water vapor and air, carbon monoxide, hydrogen, carbon dioxide, nitrogen and water vapor are formed, this mixture is called mixed or vapor-water gas.

A prerequisite for the process of gasification of plant biomass is the prevention of combustion of the gases formed in the process.

Most of the dry distillation products are capable of burning with a significant amount of heat, which leads to an increase in its calorific value (Table 1).

Table 1

Characteristics of gases

\begin{tabular}{|c|c|c|c|c|c|}
\hline \multirow{3}{*}{$\begin{array}{c}\text { Name of the } \\
\text { substance }\end{array}$} & \multirow{3}{*}{ 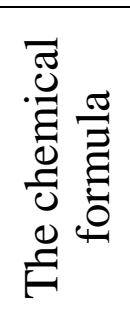 } & \multirow{3}{*}{ 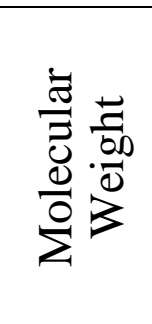 } & \multirow{3}{*}{ 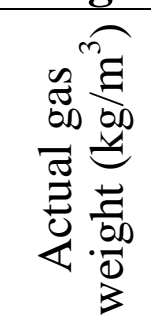 } & \multicolumn{2}{|c|}{ Calorific value } \\
\hline & & & & higher & lower \\
\hline & & & & \multicolumn{2}{|c|}{$\mathrm{MJ} / \mathrm{m}^{3}$} \\
\hline Hydrogen & $\mathrm{H}_{2}$ & 2,016 & 0,0898 & 12,8 & 10.8 \\
\hline Oxygen & $\mathrm{O}_{2}$ & 32,0 & 1,4290 & - & - \\
\hline Nitrogen & $\mathrm{N}_{2}$ & 28,016 & 1,2510 & - & - \\
\hline Carbon monoxide & $\mathrm{CO}$ & 28,01 & 1,25 & 12,6 & 12,6 \\
\hline Carbonic acid & $\mathrm{CO}_{2}$ & 44,01 & 1,977 & - & - \\
\hline Methane & $\mathrm{CH}_{4}$ & 16,04 & 0,717 & 39,8 & 35,9 \\
\hline Ethylene & $\mathrm{C}_{2} \mathrm{H}_{4}$ & 28,05 & 1,26 & 62,7 & 58,7 \\
\hline Ethan & $\mathrm{C}_{2} \mathrm{H}_{6}$ & 30,06 & 1,356 & 69,7 & 63,8 \\
\hline $\begin{array}{l}\text { Sulfuric } \\
\text { anhydride }\end{array}$ & $\mathrm{SO}_{2}$ & 64,07 & 2,927 & 4,3 & 4,3 \\
\hline $\begin{array}{l}\text { Hydrogen } \\
\text { sulfide* }\end{array}$ & $\mathrm{H}_{2} \mathrm{~S}$ & 34,09 & 1,539 & 25,1 & 23,2 \\
\hline Water vapor & $\mathrm{H}_{2} \mathrm{O}$ & 18,016 & 0,804 & - & - \\
\hline Air & - & 28,853 & 1,293 & - & - \\
\hline
\end{tabular}

* during combustion $\mathrm{H}_{2} \mathrm{O}$ and $\mathrm{SO}_{2}$ 
Obtaining air gas is accompanied by the following reactions:

$$
\begin{aligned}
\mathrm{C}+\mathrm{O}_{2} & \rightarrow \mathrm{CO}_{2}+399.8 \mathrm{~kJ} \\
2 \mathrm{C}+\mathrm{O}_{2} & \rightarrow 2 \mathrm{CO}+232.6 \mathrm{~kJ} \\
\mathrm{C}+\mathrm{CO}_{2} & \leftrightarrow 2 \mathrm{CO}-167.2 \mathrm{~kJ} \\
2 \mathrm{CO}+\mathrm{O}_{2} & \leftrightarrow 2 \mathrm{CO}_{2}+566,9 \text { кДж }
\end{aligned}
$$

Thus, as a result of combustion at excess carbon, a carbon dioxide is formed in the carbon-oxygen system, which in the presence of excess oxygen can turn into $\mathrm{CO}_{2}$. In turn, the combustion with excess oxygen ongoes with the formation of $\mathrm{CO}_{2}$, which when heated decomposes into $\mathrm{CO}$ and $\mathrm{O}_{2}$.

The reaction $\mathrm{C}+\mathrm{O}_{2}=\mathrm{CO}_{2}$ is instantaneous at temperatures of $982{ }^{\circ} \mathrm{C}$, and at lower temperatures its relative velocity is expressed by the following values: $350{ }^{\circ} \mathrm{C}-1$, at $400{ }^{\circ} \mathrm{C}-10$ and at $500{ }^{\circ} \mathrm{C}-200$.

The reaction $2 \mathrm{C}+\mathrm{O}_{2}=2 \mathrm{CO}$ is considered to be primary in carbon combustion. However, given that carbon burns directly into $\mathrm{CO}_{2}$ with subsequent recovery, (5.2) is used to express the end result of the reactions:

$$
\begin{gathered}
\mathrm{C}+\mathrm{O}_{2}=\mathrm{CO}_{2} \\
\mathrm{C}+\mathrm{CO}_{2}=2 \mathrm{CO} \\
2 \mathrm{C}+\mathrm{O}_{2}=2 \mathrm{CO}
\end{gathered}
$$

The reaction $\mathrm{C}+\mathrm{CO}_{2}=2 \mathrm{CO}$ is essential in terms of the gasgenerating process. The interaction of $\mathrm{CO}_{2}$ and carbon with $\mathrm{CO}$ production proceeds with increasing volume and negative thermal effect. According to the Le Chatelier principle, in equilibrium, with increasing pressure, the reaction must proceed towards the formation of $\mathrm{CO}_{2}$, and conversely, with decreasing pressure in the equilibrium mixture, the $\mathrm{CO}$ content should increase. Similarly, raising the temperature should cause the reaction to flow towards the formation of $\mathrm{CO}$, and vice versa.

In the mixture of gases correlating by the composition with the generator gas, the reaction of $\mathrm{CO}$ formation takes place at temperatures above $700{ }^{\circ} \mathrm{C}$, and the temperature below $700{ }^{\circ} \mathrm{C}$ leads to the decomposition of $\mathrm{CO}$. It is found that the higher the temperature, the more complete the recovery of $\mathrm{CO}_{2}$ is. It was found that at $1000{ }^{\circ} \mathrm{C}$ favorable conditions for complete recovery of $\mathrm{CO}_{2}$ in $\mathrm{CO}$ occur, while the decrease in pressure contributes to obtaining more $\mathrm{CO}$ and less $\mathrm{CO}_{2}$. 
The transformation of carbon residues into gaseous products is due to the following reactions:

$$
\begin{gathered}
\mathrm{C}+\mathrm{H}_{2} \mathrm{O} \rightarrow \mathrm{CO}+\mathrm{H}_{2}-11 \mathrm{MJ} /(\mathrm{kg} \text { of carbon }) \\
\mathrm{C}+\mathrm{CO}_{2} \rightarrow 2 \mathrm{CO}-14.6 \mathrm{MJ} /(\mathrm{kg} \text { of carbon })
\end{gathered}
$$

To accelerate the flow of gasification of plant biomass a temperature of $700{ }^{\circ} \mathrm{C}$ and heat supply in the amount of from 11 to $14.6 \mathrm{MJ}$ per $1 \mathrm{~kg}$ of carbon in the carbon residues are required.

Depending on the method of heat supply, gasification of plant biomass can be classified into autothermal and allothermal.

Depending on the composition, oxidizing medium and moisture of the source fuel, the generator gas has a combustion heat of 4 to $15 \mathrm{MJ} / \mathrm{m}^{3}$.

The allothermal method of producing combustible gases from solid fuels is based on bringing heat into the gasification zone of the solid carbon residue through the gas generator reactor vessel, or by heating the fuel particles inside the gas generator at the expense of an external coolant. Given the theoretical foundations and features of the allothermal method design, the production of gaseous fuels has not become widespread, unlike the autothermal gasification method.

Depending on the organization of the supply of oxidizer and particle size distribution of the source solid fuel they distinguish the following schemes of autothermal gasification method: in a dense layer; in a fluidized bed; in the dust stream.

Scheme of gasification in the dense layer. At gasification in a dense layer the source fuel in the form of small particles is supplied from above into the shaft of the gas generator, where the stages of drying, pyrolysis and, in fact, gasification take place. Depending on the type of fuel, its composition and moisture, a suitable drying, pyrolysis and gasification time is set, which is characterized by the height of the respective zones in the gas generator shaft.

Considering the place of supply and the type of blast (air, water vapor, oxygen) and the location of the output of the synthesis gas from the shaft they distinguish three types of gas generators with a dense layer:

- direct gasification process;

- reverse gasification process;

- horizontal gasification process.

In the direct process of gasification of raw materials, the generator gas exits from the upper part of the shaft, and the supply of air blast is carried 
out at the very bottom of the shaft gas generator, where the process of combustion of carbon residual fuel with heat and combustion products $\left(\mathrm{CO}_{2}, \mathrm{H}_{2} \mathrm{O}\right)$ takes place.

Moving from the bottom up, the products of combustion pass the entire layer of fuel in the shaft, and there is a consistent process of gasification of carbon residue and pyrolysis. Gasification products $\left(\mathrm{CO}, \mathrm{H}_{2}, \mathrm{CH}_{4}\right)$ form a cooled gas mixture that passes through the middle part of the fuel layer in a shaft where there is a process of thermal decomposition with the release of acids, resins, and gases. Further, the mixture of combustion products (generator gas) passing through the upper layer of fuel, dries it, cools down and exits at the top of the shaft of the gas generator.

The advantages of the reverse process on the purity of the generator gases are especially important in the gasification of "young" solid fuels, which emit resin and acid in large quantities during the pyrolysis.

Scheme of gasification in a fluidized bed. The characteristic difference between the method of gasification of solid fuel in the fluidized bed (Winkler's method and its modifications) in comparison with the method of gasification in the dense layer is that the fuel particles under the action of steam-air or steam-oxygen blast make continuous movement in the volume of the gas generator shaft. This movement intensifies significantly: the processes of heat and mass exchange between solid particles of fuel and the heated steam-gas environment; processes of thermochemical decomposition of solid fuels and unstable compounds formed in the process. This is favorably reflected in the uniformity of flow of the processes of gas generation gas, the increase of gas output per square unit of the cross section of the gas generator shaft, as well as the reduction of the amount of unwanted impurities in the gas and equalization of the composition of gases at the exit of the shaft.

In the case of autothermal gasification technology, the heating of the circulating solid coolant (as well as its presence) is optional, and the fluidization of the fuel particles can be carried out without recirculation, by the appropriate organization of the supply of steam-air or steam-oxygen blast.

Scheme of gasification in the dust stream. During the experimental studies of gas formation processes as a result of thermal effects on different particle sizes of fuel, a significant influence of particle size and heating rate on the intensity of gassing, composition and amount of gases formed is revealed. The smaller the particle size of the fuel, the faster and more gaseous products of thermal decomposition of plant biomass are formed. 
There are several methods of gasification of powdered solid fuels for realization of the revealed positive effects: «Koppers-Totzek», «PRENFLO» and «Texaco». In all these methods, powdered fuel with a particle size of not more than 100 microns $(0.1 \mathrm{~mm})$ is used.

According to the "Koppers-Totzek" ("PRENFLO") method, the powdered fuel is supplied by counter flows along with the oxygen blast. In the Texaco method, the powdered fuel is supplied in the form of an aqueous suspension in a stream enriched with oxygen. These methods of gasification occur at excess pressure $(1 \div 3.5 \mathrm{MPa})$ and temperature $1300 \div 1700^{\circ} \mathrm{C}$.

The advantage of the Koppers-Totzek method is the high level of conversion of the organic part of the fuel into a relatively pure resinless generator gas, as well as the ability to process almost any kind of solid fuels, regardless of their sintering.

\subsection{The structure and principle of operation of gas generating power plant}

The gas-generating energy complex (block A, figure 3) is the main component of the whole range of equipment for the disposal of disperse organic waste.

The scheme in fig. 5.1 is one of the technological options for the installation. The complex works as follows: from the receiving area the fuel (18) by grapple (3) with the help of the monorail (1) and electric hoist (2) is supplied into the buffer tank for waste (4), from where it is sent through the gateway dispenser (5) to the gas generator (6) for gasification. Then, the mineral residue in the form of ash through the hatch unloading ash (8) is shipped to the ash bunker (17), after which it is sent to consumers. In order to carry out the gasification process, the air is supplied from the blower (7) is supplied to the gas generator (6). The generated gas through the gas branch pipe (9) is sent to the cyclone (10) for cleaning of suspended particles, the cyclone is periodically unloaded through a special device in the bunker (17). Then the gas enters the radiator (11), where it is cooled. Then, the generator gas is sent to a fine gas filter (12) to remove fine dispersed solids and further cooling to a temperature below $45 \ldots 60^{\circ} \mathrm{C}$ and the resin and water vapor are condensated. The generator gas thus prepared is supplied to the consumer via the additional purification device (14). In the role of the consumer, the manufacturer recommends the use of unit of heating modular AOM-02,5 in combination with a burner of DSGM-30 (15) type, or internal combustion engine of DGMA-75 (16) type or their analogs. 


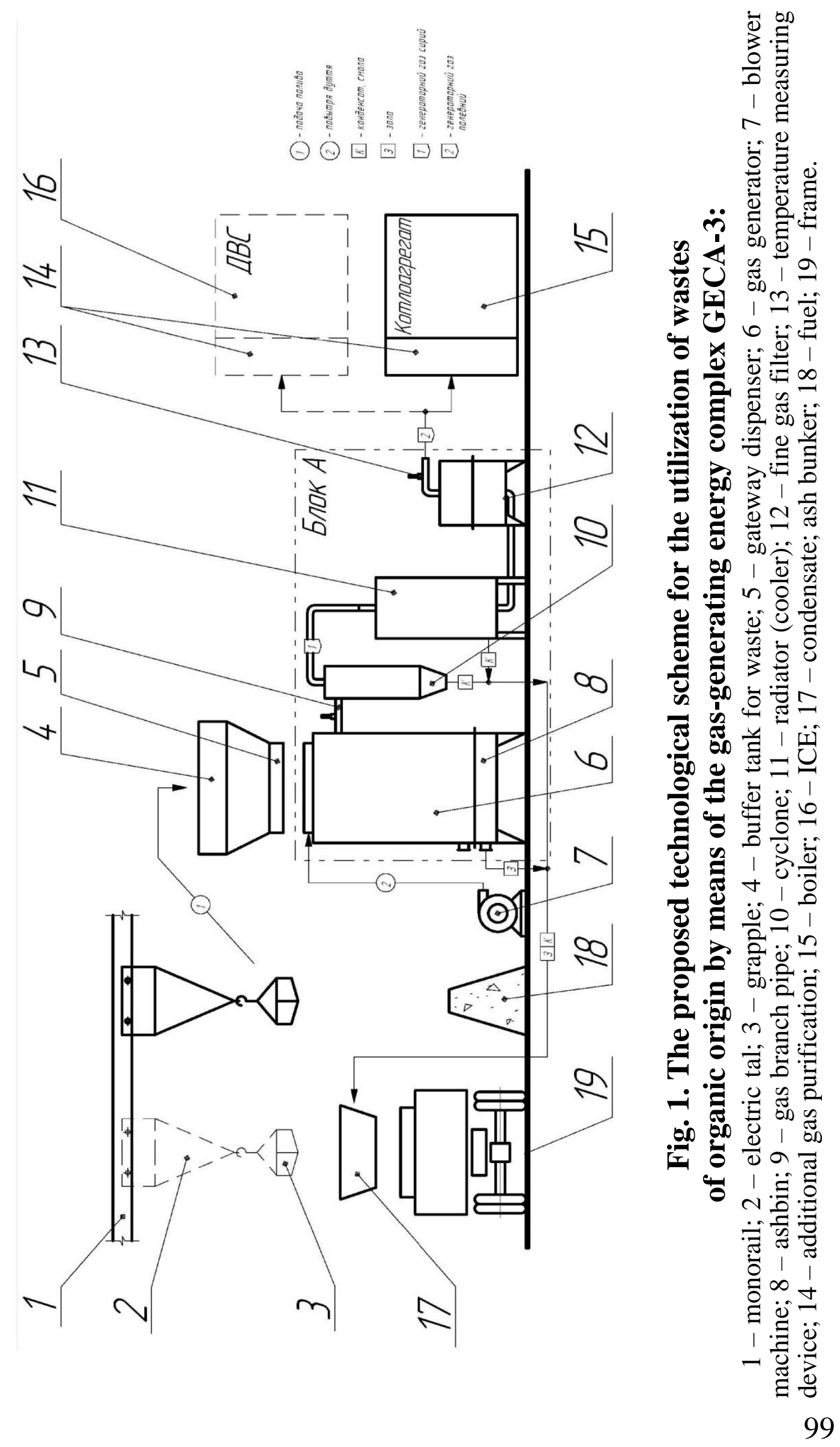




\subsection{The formulas for calculating the process of gasification of plant biomass using a gas generating power plant}

To determine the basic parameters of the gasification process it is necessary to know the elemental composition of the fuel (table 2), on which the gas-generating power plant operates, and the approximate composition of the gas that may be obtained as a result of the gasification process.

Table 2

Elemental composition of fuel

\begin{tabular}{|c|c|c|c|c|c|c|c|}
\hline \multirow[b]{2}{*}{ Fuel } & \multicolumn{2}{|c|}{ Content, $\%$} & \multicolumn{5}{|c|}{ Combustible mass, $\%$ by weight } \\
\hline & 离 & 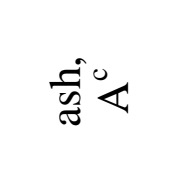 & 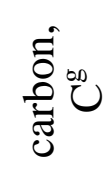 & 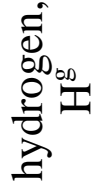 & 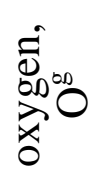 & 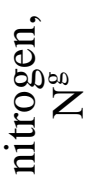 & 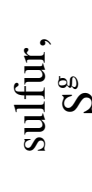 \\
\hline $\begin{array}{l}\text { wood waste - } \\
\text { technological chips } \\
\text { agricultural waste } \\
\text { (sunflower husk) }\end{array}$ & $\begin{array}{c}16 \ldots 18 \\
10\end{array}$ & $\begin{array}{c}0,4 \ldots 1,0 \\
3,5\end{array}$ & $\begin{array}{c}50,0 \\
47\end{array}$ & $\begin{array}{c}6,0 \\
6\end{array}$ & $\begin{array}{r}43,0 \\
45\end{array}$ & $\begin{array}{c}1,0 \\
1\end{array}$ & $\begin{array}{l}- \\
1\end{array}$ \\
\hline
\end{tabular}

The moisture content of the fuel $\mathrm{W}^{\mathrm{p}}$ is given in $\%$ by weight relatively to the working mass of the fuel, ashes $\mathrm{A}^{\mathrm{c}}$ - in $\%$ by weight relatively to the dry mass, other components - in $\%$ by weight relatively to the combustible mass of the fuel.

The combustible mass of the fuel consists of carbon $\mathrm{C}^{\mathrm{g}}$, hydrogen $\mathrm{H}^{\mathrm{g}}$, oxygen $\mathrm{O}^{\mathrm{g}}$, nitrogen $\mathrm{N}^{\mathrm{g}}$ and sulfur $\mathrm{S}^{\mathrm{g}}$ :

$$
\mathrm{C}^{\mathrm{g}}+\mathrm{H}^{\mathrm{g}}+\mathrm{O}^{\mathrm{g}}+\mathrm{N}^{\mathrm{g}}+\mathrm{S}^{\mathrm{g}}=100 \%=\text { fuel mass }
$$

The dry mass of the fuel consists of combustible and ash:

$$
\text { fuel mass }+\mathrm{A}^{\mathrm{c}}=100 \%
$$

To calculate the composition of the fuel from the combustible mass to dry we use the following formula (for any component):

$$
x^{c}=\frac{x^{2} \cdot\left(100-A^{c}\right)}{100} \text {. }
$$


The working mass of the fuel consists of dry weight and moisture. The conversion from dry mass to working is performed by the formula (for any component):

$$
x^{p}=\frac{x^{c} \cdot\left(100-W^{p}\right)}{100} .
$$

We convert the elemental composition of the fuel into working mass.

The conversion from combustible mass to working is performed by the formula:

$$
x^{p}=\frac{x^{2} \cdot\left(100-A^{c}\right) \cdot\left(100-W^{p}\right)}{100 \cdot 100} .
$$

Having converted the elements that make up the fuel by the formula (9) we get the composition of the working mass of the fuel.

The lower calorific value of the working mass of solid fuel is determined by the Mendeleev formula (10):

$$
H_{t}^{p}=81 \cdot C^{p}+246 \cdot H^{p}-26 \cdot\left(O^{p}-S_{n}^{p}\right)-6 \cdot W^{p} \kappa \kappa a л / \kappa 2,
$$

where $S_{n}^{p}$ is the content of volatile (combustible) sulfur in the working fuel.

Dry gas outlet from $1 \mathrm{~kg}$ of working fuel.

Considering the loss of carbon of the fuel together with the ash, as well as in the form of dust, we obtain the amount of carbon of the fuel, which has passed into the gas, per $1 \mathrm{~kg}$ of fuel:

$$
\frac{C^{p}-C_{n}}{100}
$$

where $C_{n}$ - carbon losses in ash.

The carbon content of the gas is determined by the formula

$$
\mathrm{C}^{2}=\frac{12 \cdot\left(\mathrm{CO}+\mathrm{CO}_{2}+\mathrm{CH}_{4}\right)}{22,4 \cdot 100}, \frac{\kappa 2}{\mathrm{M}^{3} \text { газу }},
$$

where 12 is the molecular weight of carbon;

22,4 - volume of one mole of gas in $\mathrm{m}^{3}$ at $0{ }^{\circ} \mathrm{C}$ and $760 \mathrm{~mm} \mathrm{Hg}$

Dividing the amount of carbon in the fuel (Formula 11) that has passed into the gas by a carbon content in $1 \mathrm{~m}^{3}$ of gas (12), we obtain the output of dry gas (5.13) from a $\mathrm{kg}$ of working fuel:

$$
V_{g}=\frac{22,4 \cdot\left(C^{p}-C_{n}\right) \cdot 100}{12 \cdot\left(C O+\mathrm{CO}_{2}+\mathrm{CH}_{4}\right) \cdot 100}=\frac{1,867 \cdot\left(C^{p}-C_{n}\right)}{\mathrm{CO}+\mathrm{CO}_{2}+\mathrm{CH}_{4}}, \frac{\mathrm{M}^{3}}{\kappa 2} \text {. }
$$


Carbon losses in ash $\mathrm{C}_{\mathrm{n}}$ are taken as $1.5 \ldots .3 \%$.

Specific weight of gas.

Specific weight of dry gas at $0{ }^{\circ} \mathrm{C}$ and $760 \mathrm{~mm} \mathrm{Hg}$ :

$$
\begin{aligned}
& \gamma_{2}=0,0125 \cdot \mathrm{CO}+0,0009 \cdot \mathrm{H}_{2}+0,0072 \cdot \mathrm{CH}_{4}+ \\
& +0,0198 \cdot \mathrm{CO}_{2}+0,0125 \cdot \mathrm{N}_{2}+0,0143 \cdot \mathrm{O}_{2}, \frac{\kappa 2}{\mathrm{M}^{3}} .
\end{aligned}
$$

Moisture content in generator gas.

The amount of water vapor contained in the generator gas consists of hygroscopic moisture, moisture supplied from the outside, moisture formed from hydrogen of fuel, not taking into account the hydrogen consumed in the formation of methane. The amount of moisture contained in $1 \mathrm{~m}^{3}$ of gas is determined by the formula:

$$
f_{2}=\frac{W^{p}+9 \cdot H^{p}}{100 \cdot V_{g}}-\frac{0,804 \cdot\left(H_{2}+2 \cdot C H_{4}\right)}{100}, \frac{\kappa 2}{M^{3}},
$$
of fuel;

where $\mathrm{W}^{\mathrm{p}}$ and $\mathrm{H}^{\mathrm{p}}$ - the percentage of moisture and hydrogen in $1 \mathrm{~kg}$

$\mathrm{H}_{2}$ and $\mathrm{CH}_{4}$ - percent of hydrogen and methane content in $1 \mathrm{~m}$ of gas;

0,804 - conditional specific weight, $\mathrm{kg} / \mathrm{m}^{3}$ of water vapor at $0{ }^{\circ} \mathrm{C}$ and $760 \mathrm{~mm} \mathrm{Hg}$, calculated by the formula: $\frac{m_{\text {води }}}{22,4}=\frac{18}{22,4}=0,804$.

The total content of water vapor in the gas resulting from gasification of $1 \mathrm{~kg}$ of fuel can be calculated by the formula:

$$
G_{\text {вод }}=f_{2} \cdot V_{g} \frac{\kappa 2}{\kappa 2_{\text {палива }}} .
$$

The output of wet gas from $1 \mathrm{~kg}$ of fuel consists of the amount of dry gas $\mathrm{V}_{\mathrm{g}}$ and the amount of water vapor $\mathrm{G}_{\text {вод. }}$ expressed in units of volume:

$$
V_{g}^{\prime}=V_{g} \cdot\left(1+1,24 \cdot f_{2}\right), \frac{M^{3}}{\kappa 2_{\text {палива }}} .
$$

Air flow rates for gasification of $1 \mathrm{~kg}$ of fuel.

To calculate the cross-section of the tuyere through which the air enters the gasification chamber, it is necessary to know the amount of air required to gasify $1 \mathrm{~kg}$ of fuel.

The air flow rate is determined on the basis of the nitrogen balance, which changes from air to gas during the gasification of the fuel. Knowing 
that $1 \mathrm{~m}^{3}$ of air contains $79 \%$ nitrogen (by volume), and $1 \mathrm{~m}^{3}$ of gas contains $\mathrm{N}_{2} \%$ nitrogen, we conclude - the formation of $1 \mathrm{~m}^{3}$ of gas consumes $\frac{N_{2}}{79}$ air. Then for gasification of $1 \mathrm{~kg}$ of fuels it is necessary to:

$$
L=V_{g} \cdot \frac{N_{2}}{79}=0,0127 \cdot V_{g} \cdot N_{2}, \frac{M^{3}}{\kappa 2} .
$$

Material balance.

According to the law of conservation, the amount of substance used for gasification of $1 \mathrm{~kg}$ of fuel should be equal to the amount of substance obtained as a result of the gasification process of the fuel. Material balance of gasification process:

$$
1,0+1,293 \cdot L=\gamma_{2} \cdot V_{g}+G_{\text {вод }}+0,01 \cdot A^{p}+0,01 \cdot C_{n},
$$

where 1.00 - weight of fuel in working condition;

1,293 - specific weight of air at $0{ }^{\circ} \mathrm{C}$ and $760 \mathrm{~mm} \mathrm{Hg}$;

$1,293 \mathrm{~L}$ - weight of air consumed for gasification;

$\gamma_{2} \cdot V_{g}$ - weight of dry gas formed in the process of gasification of fuel;

$\mathrm{G}_{\text {вод. }}-$ weight of water vapor resulting from the gasification process of the fuel;

$0.01 \cdot \mathrm{A}^{\mathrm{p}}-$ weight of ash;

$0.01 \cdot \mathrm{C}_{\mathrm{n}}-$ Carbon loss with ash and dust.

The amount of $\mathrm{H}_{2}$ and $\mathrm{O}_{2}$ is insignificant so it is not taken into account. Taking into account the possible variations in the composition of the generator gas with respect to the set fuel composition, as well as rounding in the calculations, it is possible to allow a difference in the material balance within $\pm 3 \%$.

The efficiency of the gas generator.

Efficiency of gas-generating power plant is determined by the formula

$$
\eta_{2}=\frac{V_{g} \cdot H_{u}}{H_{H}^{p}}
$$

where $\eta_{2}$ - gas generator efficiency; $H_{u}^{p}-$ calorific value of the working fuel in $\mathrm{kcal} / \mathrm{m}^{3} ; V_{g}$ - gas output from $1 \mathrm{~kg}$ of fuel $\mathrm{m}^{3} / \mathrm{kg} ; H_{u}-$ lower calorific value of gas at $0{ }^{\circ} \mathrm{C}$ and $760 \mathrm{~mm} \mathrm{Hg}$ in $\mathrm{kcal} / \mathrm{m}^{3}$. 
Lower calorific value of gas is calculated by the formula:

$$
H_{u}=30,35 \cdot \mathrm{CO}+25,7 \cdot \mathrm{H}_{2}+85,7 \cdot \mathrm{CH}_{4} \frac{\kappa \kappa a \Omega}{\mathrm{M}^{3}} .
$$

Thermal power of the gas generator.

Taking into account the data of the formulation of the task for the experimental design work, the thermal capacity of the gas-generating plant $\mathrm{N}_{\mathrm{y}}$ should be in the range from $100 \mathrm{~kW}$ to $400 \mathrm{~kW}$.

Knowing that $1 \mathrm{~kW}=1 \mathrm{~kJ} / \mathrm{s}=3600 \mathrm{~kJ} / \mathrm{h}$ and $1 \mathrm{~kJ}=4.19 \mathrm{kcal}$ from here

$1 \mathrm{~kW}=3600 / 4.19=860 \mathrm{kcal} / \mathrm{h}$, we have

$$
\left\{\begin{array}{l}
\mathrm{N}_{\mathrm{y}}=100 \mathrm{~kW}=86000 \mathrm{kcal} / \mathrm{h} . \\
\mathrm{N}_{\mathrm{y}}=250 \mathrm{~kW}=215000 \mathrm{kcal} / \mathrm{h} . \\
\mathrm{N}_{\mathrm{y}}=400 \mathrm{~kW}=344000 \mathrm{kcal} / \mathrm{h} .
\end{array}\right.
$$

Having previously calculated by the formula (50) the lower calorific value of gas of a given fuel composition, we find the required power of the gas generator on the produced gas $N_{2}$ :

$$
N_{z}=\frac{N_{y}}{H_{u}}, \frac{\mathcal{M}^{3}}{20 \partial} .
$$

Fuel consumption.

Knowing the gas output $\mathrm{V}_{\mathrm{g}}$ from $1 \mathrm{~kg}$ of fuel, we find the amount of gas required for gas production:

$$
G_{T}=\frac{N_{2}}{V_{g}}, \frac{\kappa 2}{20 \partial} .
$$

The amount of air required to burn $1 \mathrm{~m}^{3}$ of synthesis gas.

When burning synthesis gas, air flow rate is determined by the ratio:

$$
L_{0}=\frac{1}{21} \cdot\left[0,5 \cdot\left(\mathrm{CO}+\mathrm{H}_{2}\right)+2 \cdot \mathrm{CH}_{4}-\mathrm{O}_{2}\right] \frac{\mathrm{M}^{3}}{\mathcal{M}_{\text {газу }}^{3}} .
$$

The calorific value of the gas-air mixture is determined by the formula:

$$
h_{u}=\frac{k \cdot H_{u}}{1+\alpha \cdot L_{0}}, \frac{\kappa \kappa a л}{M^{3}},
$$

where $\mathrm{k}=0.92$ and $\alpha=1$. 


\section{CONCLUSIONS}

1. Ukraine has unique natural and climatic conditions and is a favorable region for energy efficient alternative energy technologies.

2. On the basis of modern methods and energy-efficient technologies, based on the techniques of biological intensification, technologies of increasing the efficiency of photosynthesis at the expense of prolonged use of solar energy have been developed.

3. The economically viable biomass potential that can be used for energy purposes in Ukraine is estimated at 30 million tonnes of conventional fuel per year. Its main constituents are agricultural waste and energy agroindustrial crops. By engaging them in energy production about 13 percent of Ukraine's primary energy needs can be met.

\section{Information about the author:} Medvediev M. H. Doctor of Technical Sciences, Professor,

Head at the General Engineering and Thermal Power Engineering Department of the V. I. Vernadsky Taurida National University 